EGU2020-20657, updated on 31 Jan 2022

https://doi.org/10.5194/egusphere-egu2020-20657

EGU General Assembly 2020

(c) Author(s) 2022. This work is distributed under

the Creative Commons Attribution 4.0 License.

\title{
Plant available silicon in bare fallow soils after 90 years of annual supplies of manure, lime and fertilizers
}

\author{
Zimin $\mathbf{L i}^{1}$, Jean-Dominique Meunier ${ }^{2}$, Folkert Van-Oort ${ }^{3}$, Catherine Keller ${ }^{2}$, and Bruno Delvaux ${ }^{1}$ \\ ${ }^{1}$ Université Catholique de Louvain (UCLouvain), Earth and life Institute, Soil Science, Louvain-La-Neuve, Belgium \\ (zimin.li@uclouvain.be) \\ ${ }^{2}$ CNRS, IRD, Coll France, CEREGE, Aix Marseille Université, 13545 Aix-en-Provence Cedex 04, France \\ ${ }^{3}$ INRA/AgroParisTech, UMR 1402 ECOSYS, Équipe Ecotoxicologie, RD-10, F-78026 Versailles Cedex, France
}

Silicon (Si), non-essential but beneficial to plants, plays a crucial role in maintaining plant functions by alleviating a number of biotic and abiotic stresses. Applying manure, lime and chemical fertilizers to soils may impact the pool of plant available Si, but their impact over decades to century is unknown.

Here, we determined the evolution of the content of plant available Si in a silty soil derived from Quaternary loess (Haplic Luvisol), submitted to a long-term bare fallow experiment initiated in 1928 in Versailles (INRA, France). On this bare fallow soil, different treatments were applied annually since 1929 , among which, manure, lime $\left(\mathrm{CaCO}_{3}\right), \mathrm{NaNO}_{3}$ and $\left.\left(\mathrm{NH}_{4}\right)_{2} \mathrm{SO}_{4}\right)$ and compared to control soil. Archived soil samples were already characterized for their basic properties $(\mathrm{pH}, \mathrm{CEC}$, OC, N, oxalate-extractable Al, Fe and Si, DCB extractable Fe, particle size distribution, elemental analysis). Here, we computed the total reserve in bases (TRB), and we determined the content of plant available $\mathrm{Si}\left(\mathrm{CaCl}_{2}\right.$-Si) through a kinetical extraction using $0.01 \mathrm{M} \mathrm{CaCl}_{2}$.

TRB was $110 \mathrm{cmol}(+) \mathrm{kg}^{-1}$ in 1929. During the 90 years period, TRB (cmol (+) $\mathrm{kg}^{-1}$ ) remained constant in manured plots, decreased to 96 in control/ $/ \mathrm{NaNO}_{3}$ plots and to 84 in the $\left(\mathrm{NH}_{4}\right)_{2} \mathrm{SO}_{4}$ plot whereas it increased to 160 in the $\mathrm{CaCO}_{3}$ plot. The initial $\mathrm{CaCl}_{2}-\mathrm{Si}$ content did not differ between the treatments, as it ranged between 25 and $30 \mathrm{mg} \mathrm{kg}^{-1}$ in 1929. Annual manure supply resulted in the progressive increase of $\mathrm{CaCl}_{2}-\mathrm{Si}$ up to $60 \mathrm{mg} \mathrm{kg}^{-1}$. In this treatment, $\mathrm{CaCl}_{2}-\mathrm{Si}$ (30 to $60 \mathrm{mg} \mathrm{kg}^{-1}$ ) and $\mathrm{OC}$ (18 to $40 \mathrm{~g} \mathrm{~kg}^{-1}$ ) contents were strongly and positively correlated, suggesting the continuous silicon through manure supply (probably phytoliths), and their dissolution at $\mathrm{pH}$ 6.6-7.6. In the four other treatments, OC content regularly decreased from 18 to $5 \mathrm{~g} \mathrm{~kg}^{-1}$ from 1929 to 2019 , but $\mathrm{CaCl}_{2}-\mathrm{Si}$ largely differed between them. Our data suggest a strong impact of $\mathrm{pH}$ on $\mathrm{CaCl}_{2}-\mathrm{Si}$ as well as the occurrence of two sources of bioavailable Si: phytoliths in limed plots $(\mathrm{pH}$ 6.6 to 8.8) and clay minerals in acidified plots submitted to annual $\left(\mathrm{NH}_{4}\right)_{2} \mathrm{SO}_{4}$ application ( $\mathrm{pH}$ from 6 to 3.5$)$.

Our preliminary results show that, in a given soil type, the pool of bioavailable silicon is strongly affected by soil properties, especially soil $\mathrm{pH}, \mathrm{OC}$ content and weathering stage. 
